\title{
Rola Kościoła partykularnego w procedurze mianowania biskupów przez papieża
}

Serdecznie dziękuję za zaproszenie na to sympozjum, poświęcone ważnej sprawie, która również związana jest dość organicznie z posługą nuncjusza w danym kraju. Dziękuję też za miłe słowa powitania. Przed chwilą Ksiądz Kardynał Prymas Erdő przedstawił władzę papieża w zakresie nominacji biskupich. Moim zadaniem jest przedstawienie, jak w pełnieniu tej władzy wspomaga papieża Kościół lokalny.

Od wieków nominacje biskupów należały w Kościele do spraw szczególnie ważnych, a jednocześnie delikatnych. Oczywiście podlegały one również pewnej ewolucji, uzależnionej od rozwoju teologii, a zwłaszcza eklezjologii.

W kościelnych wspólnotach pierwotnych, z uwagi na religijny zapał ich członków, sens współuczestniczenia i samoświadomość wspólnot, siłą rzeczy mocno ograniczonych liczebnie, stosunkowo łatwe było skuteczne włączanie tych wspólnot w proces nominacji biskupich. Najczęściej wspólnota pierwotna doświadczała prześladowań, a w najlepszym przypadku była całkowicie odizolowana od władzy świeckiej i całkowicie wobec niej autonomiczna. Z kolei władza świecka starała się nie mieszać do spraw wewnętrznych wspólnot religijnych. 
Od czasów apostolskich takie ustawienie sprawy nominacji biskupich było pojmowane jako wymóg wierności wspólnoty chrześcijańskiej wobec Chrystusa. Można znaleźć podobne wskazania w listach apostolskich, zwłaszcza do Tymoteusza i Tytusa.

Rozwój - także liczebny - wspólnot chrześcijańskich, osłabienie pierwotnej gorliwości i samoświadomości chrześcijan w epoce pokoju Konstantyńskiego, większa hierarchizacja tej wspólnoty, a przede wszystkim spotkanie chrześcijaństwa z filozofią platońską, skutkowały większą koncentracją spraw związanych z nominacjami w rękach duchowieństwa (wyższych duchownych i kapituł kanonickich) oraz świeckiej władzy książąt.

Platońska idea Boga Jedynego, całkowicie transcendentnego, całkowicie innego, do którego można dotrzeć jedynie przez „kogos’”, powodowała, że dużej wagi nabierali pośrednicy, którzy byli bliżej Boga: kapłan, jeśli chodzi o sferę kultową, oraz książę, jeśli chodzi o sferę doczesną i ustanawiane prawa. To było tłem do zmian w teologii, które swoje zinstytucjonalizowane oblicze znalazły w reformie gregoriańskiej (papieża Grzegorza VII, który zmarł w roku 1085). Takie określenia jak: Summus Pontifex (Najwyższy Kapłan), Vicarius Christi (Zastępca-Wikariusz Chrystusa) czy sacerdos alter Christus (kapłan drugi Chrystus) wskazywały, że święta władza przechodziła od Boga na jego Wikariusza, zastępcę na ziemi, a od niego - na biskupów i kapłanów. Laikat pozostawał poza tą logiką „władzy”. Jest oczywiste, że w świetle tej teologii i filozofii, jak również z uwagi na coraz bardziej powierzchowne wykształcenie i formację wiernych świeckich, sprawa nominacji biskupich zostawała coraz bardziej w rękach wyższego kleru.

Również powiększała się rola władzy świeckiej, jako mediatora w sprawach nominacji biskupich. Przez wieki królowie i władcy świeccy otrzymywali swoiste namaszczenie religijne, chrześcijańskie. Stąd też chełpili się posiadaniem wrodzonego prawa do uczestniczenia w wykonywaniu władzy kościelnej. Tak zrodziła się instytucja inwestytury świeckiej, z którą Kościół walczył, przede wszystkim z powodu związanej z nią nierzadko symonii. Gdy Grzegorz VII zaczął zwalczać inwestyturę świecką, zdawał sobie sprawę, że staje w opozycji do instytucji niepozbawionej całkowicie podstaw prawnych: król, władca świecki wraz z konsekracją wkraczali w obszar religijny, kościelny. Zaczął jednak zwalczać inwestyturę z uwagi na towarzyszącą jej często symonię. Dopiero jednak w 1122 roku podpisany został konkordat z Worms, który usankcjonował inwestyturę kościelną biskupów (przekaza- 
nie pierścienia i pastorału) ze strony papieża oraz inwestyturę świecką (feudalna) ze strony księcia (władzy świeckiej). Jeden z artykułów tego konkordatu przewidywał udział imperatora, księcia (władzy świeckiej) w samym akcie wyboru biskupa.

Następnie, w 1516 roku, konkordat boloński przekazywał królowi Franciszkowi I prawo wyboru biskupów we wszystkich diecezjach francuskich, podczas gdy papież dokonywał jedynie inwestytury. Podobnie stanowił konkordat Napoleoński z 1801 roku. Analogiczne rozwiązania przyjął konkordat z Hiszpanią z 1753 roku oraz konkordat z imperatorem austriackim z 1855 roku. Począwszy od drugiej połowy XIX wieku, państwa Ameryki Łacińskiej, odzyskując niepodległość, zawierały z papieżem konkordaty dające im podobne gwarancje.

Na początku XIX wieku, na około sześciuset biskupów, jedynie dwudziestu siedmiu było mianowanych bezpośrednio przez papieża. Wiele państw, w tym również europejskich, zależało wówczas jeszcze od Kongregacji Rozkrzewiania Wiary. Stolica Apostolska udzieliła im (Irlandia, Anglia, Szkocja, Holandia, Stany Zjednoczone Ameryki, Australia) prawa przesyłania do Rzymu terny kandydatów, zdatnych do objęcia wakujących stolic biskupich. Prawnie wyznaczonymi do przedstawiania tej listy kandydatów były zazwyczaj kapituły kanonickie, a w niektórych krajach także proboszczowie nieusuwalni. Jak więc widać, uczestnictwo kapłanów w procesie przedstawiania kandydatów na biskupstwa było dość szerokie.

Reforma Kurii Rzymskiej w 1908 roku, przeprowadzona przez papieża Piusa X, przeniosła wiele krajów spod kompetencji Kongregacji Rozkrzewiania Wiary pod kompetencję Kongregacji Konsystorialnej (tak wówczas nazywała się dzisiejsza Kongregacja Biskupów). W takim stanie rzeczy Stolica Apostolska zmieniła system przedstawiania ad hoc terny kandydatów na system przedstawiania ogólnej listy kandydatów do biskupstwa, przygotowywanej już nie przez kapituły kanonickie, lecz przez biskupów. I tak na przykład, Kongregacja Konsystorialna postanowiła, że biskupi Stanów Zjednoczonych Ameryki, Kanady, Szkocji, Brazylii, Meksyku, Polski i innych, co pięć lat mają przygotowywać listę kandydatów i przekazwać ją do Rzymu. Dla innych krajów, takich jak Włochy, Belgia, Portugalia, Jugosławia, Czechosłowacja czy Rumunia, przyjęto zasadę „sugestii na prośbę”, czyli że biskupi, indywidualnie lub grupowo, przekazywali swoje sugestie odnośnie do nazwisk kandydatów jedynie wtedy, gdy o to wprost zostali poproszeni z Rzymu. 
Promulgowany w 1917 roku Kodeks prawa kanonicznego stwierdzał krótko: Biskupi są mianowani w sposób nieskrępowany przez papieża (kan. 329 $\$ 2$ ). Była to znacząca innowacja prawna. Aż do tamtego czasu obowiązywała zasada wyboru biskupa i nie została ona wcześniej formalnie zniesiona. Natomiast kodeks ustanowił generalną zasadę "nominacji” papieskiej, podczas gdy wybór został określony jako „ustępstwo” czy „przywilej” i mógł być udzielony tylko przez najwyższą władzę kościelną. Rzeczywiście, kan. 329 dawnego kodeksu, w paragrafie drugim sankcjonował „nominacje”, a w paragrafie trzecim dodawał: „Kolegium, któremu udzielone zostało prawo wyboru biskupa, powinno postępować zgodnie z kanonem 321" (ustala on zasadę większości absolutnej przy wyborze).

Sobór Watykański II potwierdził ogólną zasadę, że biskupi są mianowani przez papieża. Usankcjonował jednocześnie precyzyjne zasady, na jakich w wypracowaniu tej decyzji mają udział poszczególni biskupi, Konferencje Episkopatów i przedstawiciele konkretnej wspólnoty diecezjalnej.

Numer 20. soborowego dekretu Christus Dominus odnosi się do przywilejów, jakie otrzymali niektórzy szefowie państw lub rządów w zakresie przedstawiania kandydatów do biskupstwa, a w niektórych przypadkach nawet do uczestniczenia w nominacjach biskupich. Ojcowie soborowi jednoznacznie stwierdzili, że „(..) prawo nominacji i ustanawiania biskupów jest własnym, specjalnym i z natury rzeczy wyłącznym prawem kompetentnej władzy kościelnej. W związku z tym pozostaje życzeniem Świętego Soboru, aby - dla należytego strzeżenia wolności Kościoła oraz lepszego i łatwiejszego pomnażania dobra wiernych - nie przyznawano już więcej na przyszłość władzom świeckim żadnych praw czy przywilejów wyboru, mianowania, przedstawiania lub wyznaczania na urząd biskupi. Władze zaś świeckie, których przychylne nastawienie do Kościoła święty Sobór z wdzięcznością uznaje i bardzo ceni, prosi bardzo uprzejmie, aby samorzutnie, po porozumieniu się ze Stolicą Apostolską, zechciały się zrzec wspomnianych praw czy przywilejów, przysługujących im dotychczas na mocy umowy lub też zwyczaju”.

Pierwszym państwem, które zrzekło się takich przywilejów, była Argentyna. Tymczasem Francja zachowuje do dziś prawo, przyznane jej w konkordacie Napoleońskim, obowiązującym ciągle na terenie Alzacji i Lotaryngii. Zgodnie z tym konkordatem, prezydent Francji, co do zasady, ma prawo mianowania arcybiskupa Strasburga i biskupa Metz. W praktyce jednak ogranicza się obecnie do opublikowania w państwowym biuletynie oficjalnym nazwi- 
ska nowego biskupa tych diecezji z niewielkim wyprzedzeniem w stosunku do publikacji dokonywanej przez Stolicę Apostolską.

Motu proprio Ecclesiae Sanctae z 1968 roku, zawierające normy wykonawcze do niektórych dekretów soborowych, ustanawia ogólną zasadę, obowiązującą w Kościele rzymskokatolickim, dotyczącą wyłaniania kandydatów do biskupstwa. W numerze 10. można przeczytać: „Z zachowaniem prawa do swobodnego mianowania biskupów i powierzania im urzędów przez papieża, jak również dyscypliny obowiązującej w Kościołach obrządku wschodniego, konferencje episkopatów każdego roku powinny w sposób poufny omówić roztropnie kandydatury kapłanów godnych promocji biskupiej i przedstawić Stolicy Apostolskiej nazwiska kandydatów, zgodnie z normami Stolicy Apostolskiej, już obowiązującymi i które zostaną ustanowione w przyszłości”.

Normy takie zostały ustanowione w 1972 roku przez ówczesną Radę do Spraw Publicznych Kościoła i nosiły nazwę: Normy dotyczace promowania do biskupstwa w Kościele tacińskim. Zostały one później włączone do Kodeksu prawa kanonicznego 1983 roku, syntetycznie w tym, co należało do ich istoty (kan. 377 i 378 oraz kan. 364, nr 4). Nawet jeśli Kodeks prawa kanonicznego uchylił uprzednie ustawy w materii, która została w całości unormowana przez tenże kodeks, to jednak z powodów metodologicznych należy brać pod uwagę poprzednie Normy, gdyż mają one bardzo szczegółowy charakter.

Studium porównawcze Norm z 1972 roku i odpowiednich kanonów Kodeksu prawa kanonicznego ukazują pewne różnice normatywne tych dwóch dokumentów. Ważne jest ich przeanalizowanie, aby ustalić pro certitudine giuridica ich autentyczną interpretację.

W 1998 roku Sekretariat Stanu powołał komisję, złożoną z kanonistów, w celu przeanalizowania tych norm. Miałem zaszczyt i przyjemność uczestniczenia w jej pracach. Trudności hermeneutyczne ogniskowały się na dwóch zasadniczych kwestiach: roli Konferencji Episkopatów i przedstawicielstw papieskich oraz sposobach konsultacji i wymagań odnośnie do zdatności kandydatów.

Myślę, że będzie pożyteczna krótka charakterystyka Norm, aby ukazać, jaki udział w kształtowaniu decyzji o nominacji swojego biskupa ma Kościół partykularny. Analiza ta będzie też pomocna do ukazania interpretacji, jakiej dokonała wskazana wcześniej komisja odnośnie do różnic występujących w obu tekstach normatywnych. Interpretacja ta została później zakomuni- 
kowana przedstawicielom papieskim pismem okólnym Sekretariatu Stanu z 1998 roku.

Normy szczegółowo określają udział Kościoła partykularnego w wypracowywaniu nominacji ich własnych biskupów. Udział ten może mieć miejsce na trzech poziomach, obejmując: udział poszczególnych biskupów, konsultację na poziomie prowincji kościelnej oraz włączenie w nią niektórych kapłanów, osób konsekrowanych i wiernych świeckich.

Odnośnie do udziału poszczególnych biskupów Normy wypowiadają się $\mathrm{w}$ artykule pierwszym:

„1. Biskupi mają prawo i obowiązek przekazania do Stolicy Apostolskiej nazwisk kapłanów, których uważają za godnych i właściwie zdalnych do przyjęcia urzędu biskupiego, nie tylko spośród kleru diecezjalnego, ale również z kapłanów zakonnych, którzy na terenie ich diecezji wypełniają swoją posługę lub wypełniają ją gdzie indziej, ale są dobrze im znani.

2. Poszczególni biskupi diecezjalni i inni ordynariusze miejsca, z wyłączeniem wikariuszy generalnych, spełniając to ważne i delikatne zadanie, powinni zebrać informacje oraz istotne fakty, odpowiadając osobiście na przedstawione pytania i konsultując, w ramach swojej jurysdykcji i w odpowiednim zakresie czy to kapłanów należących do kapituły katedralnej, czy też konsultorów lub członków rady kapłańskiej, albo innych jeszcze duchownych diecezjalnych i zakonnych oraz osoby świeckie; konsultacja powinna być przeprowadzona indywidualnie.

3. Jeśli chodzi o jednostki organizacyjne Kościoła, powierzone instytutom misyjnym, uznaje się prawo odpowiednich przełożonych generalnych, zgodnie z praktyką Kongregacji do Spraw Ewangelizacji Narodów, do przedstawiania kandydatów z własnego instytutu, zawsze jednak z zachowaniem prawa Stolicy Apostolskiej do podjęcia innych decyzji, jeśli to wydałoby się bardziej stosowne".

Normy podkreślają, że konsultacje w omawianej materii winny być przeprowadzane indywidualnie, a nie zbiorowo. Chodzi o uniknięcie wpływu grup nacisku, który w pewien sposób mógłby ograniczyć wolność nominacji, należącej do papieża.

Zachowując prawo poszczególnych biskupów do przedstawiania kandydatów bezpośrednio Stolicy Apostolskiej, artykuł 2., ustęp 2. przewiduje, że kandydatury biskupie winny być przedyskutowane i przedstawione podczas zebrania biskupów. Podczas gdy Normy mówią o uprawnieniu po- 
szczególnych biskupów do przedstawiania kandydatów, Kodeks prawa kanonicznego w kan. 377 na pierwszym miejscu stawia procedurę kolegialną; dopiero później mówi się, że - niezależnie od tego (seorsim) - poszczególni biskupi mogą wskazywać nazwiska kandydatów bezpośrednio do Stolicy Apostolskiej.

Interpretacja z roku 1998 precyzuje, że owo seorsim, użyte w kodeksie, pozostawia nienaruszone prawo poszczególnych biskupów do przedstawiania kandydatów. Dopowiada również, że biskupi czy to indywidualnie, czy w ramach zebrania metropolitalnego, swoje kandydatury przekazują za pośrednictwem przedstawiciela Stolicy Apostolskiej. Rzeczywiście, zgodnie z duchem tak Norm, jak i kodeksu, do przedstawiciela papieskiego należy komunikowanie Stolicy Apostolskiej tego wszystkiego, co dotyczy nominacji biskupich, łącznie ze swoją osobistą opinią.

Uczestniczenie lokalnej wspólnoty w procedurze nominacji pasterzy ich diecezji, w sposób bardziej szczegółowy określone jest w art. 12 i 13 Norm.

„Jeśli chodzi o obsadzenie diecezji - precyzuje art. 13 - przedstawiciel papieski poprosi wikariusza kapitulnego [dziś - administratora diecezji] lub administratora apostolskiego lub też samego biskupa diecezjalnego o obszerny i szczegółowy raport o stanie i potrzebach diecezji; o to samo mogą być również zapytani przedstawiciele duchowieństwa i świeckich, zwłaszcza należący do istotnych instytucji kościelnych, jak również osoby zakonne.

$\mathrm{Z}$ zachowaniem prawnych wyjątków, ustanowionych prawem partykularnym lub prawnym zwyczajem, albo też z innych jeszcze racji, pozostaje zadaniem przedstawiciela papieskiego, celem sformułowania tak zwanej «terny» kandydatów, przedstawianych Stolicy Apostolskiej, indywidualne zebranie i zakomunikowanie Stolicy Apostolskiej, wraz ze swoją opinią, sugestii metropolity i sufraganów, należących do danej prowincji kościelnej lub włączonej do danego zebrania metropolitalnego, jak również opinię przewodniczącego miejscowej konferencji episkopatu. Ponadto, przedstawiciel papieski powinien wysłuchać, jeśli jest to wskazane, niektórych przedstawicieli kapituły katedralnej lub konsultorów diecezji, i innych duchownych diecezjalnych i zakonnych, zwłaszcza należących do rady kapłańskiej, ukonstytuowanej przed zawakowaniem stolicy biskupiej”.

W art. 12, natomiast, można przeczytać: „Zanim ktoś zostanie mianowany biskupem, Stolica Apostolska przeprowadza w stosunku do niego staranne i szerokie badanie, konsultując indywidualnie te osoby, które go dobrze znają 
i są w stanie przekazać informacje, możliwie najpełniejsze, oraz rozsądny osąd wyrażony «coram Domino».

Przeprowadzenie tego badania jest powierzone przedstawicielowi papieskiemu, który przesyła stosowny kwestionariusz do duchownych: biskupów, kapłanów i zakonników. Mogą być także konsultowane, w taki sam sposób, osoby świeckie, roztropne i godne zaufania, posiadające informacje o kandydacie, które warto poznać”.

Są więc trzy kategorie osób, zaproszonych do uczestniczenia w procesie wypracowywania nominacji na biskupa diecezjalnego:

- $\quad$ przede wszystkim poszczególni biskupi, którzy mają prawo wskazywać kandydatów na urząd biskupi bezpośrednio Stolicy Apostolskiej;

- jednak zwyczajnie (tekst łaciński używa terminu regulariter) odbywa się to na zebraniach metropolitalnych, które przynajmniej co trzy lata powinny przedstawiać zaktualizowane listy kandydatów zdatnych do biskupstwa (episcopabiles);

- po trzecie, jeśli chodzi o obsadzenie konkretnej diecezji, współuczestniczenie w wypracowywaniu nominacji biskupiej jest bardziej szczegółowe i dotyczy całej wspólnoty lokalnej. Nuncjusz jest zobowiązany do konsultowania się z bardziej reprezentatywnymi członkami poszczególnych grup tej wspólnoty kościelnej: prezydium Konferencji Episkopatu, metropolity i jego biskupów sufraganów, zarządzających diecezją, poszczególnych kapłanów, zakonników i świeckich.

Podczas gdy Normy, w art. 13, polecają, aby przedstawiciel papieski wysłuchał (audiet - tryb oznajmujący czasu przyszłego) prezydium Konferencji Episkopatu, metropolitę i jego biskupów sufraganów oraz niektórych członków diecezjalnych gremiów doradczych, kan. 377 kodeksu, nr 3, używa trybu nakazującego (esortativo) - audiat - który oznacza pewien obowiązek powstający po stronie przedstawiciela papieskiego. Podobnie, używając czasownika exquirat, kodeks kieruje do nuncjusza jasno określone wezwanie do zebrania opinii poszczególnych kapłanów i osób świeckich. Interpretacja z 1998 roku podkreśla, że sformułowania użyte w kodeksie oznaczają, iż konsultacji tej nie można pominąć.

Normy polecają, aby konsultacja była przeprowadzona indywidualnie (singillatim). Można więc na zebraniach publicznych, pod przewodnictwem biskupa, jego delegata czy nawet nuncjusza apostolskiego, wysłuchać zdania ich uczestników na temat sytuacji panującej w diecezji, wyzwań, realizowa- 
nych przedsięwzięć, problemów i zaległości w danej diecezji, a nawet opinii, czym powinien charakteryzować się przyszły biskup. Jednak wskazywanie nazwisk konkretnych kandydatów na ten urząd, dyskusja na temat konkretnych osób na takim spotkaniu nie są dopuszczalne. I to dla dwóch racji. Po pierwsze, w celu zagwarantowania wolności, jaką winien mieć papież w podejmowaniu takiej decyzji, bez żadnych ograniczeń ze strony swoistego lobby czy innych grup nacisku. Po drugie zaś, aby zachować prawo do prywatności (privacy) zarówno konsultowanych, jak i kandydatów. Interpretacja z 1998 roku w pełni potwierdza konieczność zachowania indywidualnego charakteru takiej konsultacji.

$\mathrm{Z}$ podobnych racji, cała procedura konsultacyjna odbywa się pod sekretem papieskim, przede wszystkim w tym, co dotyczy osób przedstawianych kandydatów.

Indywidualny charakter takiej konsultacji musi w sposób konieczny ograniczyć zakres włączonych w nią osób. W przypadku obsadzania diecezji, prośbę o wyrażenie swojej opinii wysyła się do 60-70 osób. Ponadto, gdy już wyłania się terna kandydatów, prosi się po 25 osób o wyrażenie opinii o każdej z tych 3 osób. Nawet więc jeśli konsultacja nie dociera do każdej z osób należących do danej wspólnoty diecezjalnej, to jednak konsultowana jest jej dobrze reprezentatywna grupa.

Warto zwrócić uwagę na wymagania, jakie stawiane są kandydatom do biskupstwa. Normy mówią o nich w art. 6. Kodeks, który zazwyczaj jest bardziej oszczędny w słowach niż Normy, w tym temacie jest bardziej kompletny i precyzyjny. Stąd też interpretacja z 1998 roku każe wziąć pod uwagę kan. 378, a nie art. 6 Norm.

Podobnie do grup uczestniczących w konsultacji, także Kościół partykularny bierze w niej udział na trzy główne sposoby:

- przede wszystkim przez formułowanie listy kandydatów. Jak widzieliśmy wcześniej, w procesie tym uczestniczą biskupi, indywidualnie i na zebraniach metropolitalnych;

- następnie jest to dyskusja na temat stanu diecezji, w której uczestniczy - w konsultacji pisemnej - około 70 osób z danej diecezji i metropolii;

- i w końcu, gdy pojawiają się już kandydaci, których można włączyć do terny, lokalna wspólnota jest proszona o przekazanie opinii o zdalności kandydata do posługi biskupiej, bazującej na osobistej 
i bezpośredniej znajomości kandydata. W takiej konsultacji pisemnej o każdym kandydacie uczestniczy zazwyczaj 25 pięć osób: biskupi, kapłani, osoby zakonne i świeccy, którzy dobrze znają kandydata.

Jeden z moich byłych nuncjuszy miał zwyczaj opisywać ten proces, odbywający się w trzech fazach, w bardzo sympatyczny sposób. Mawiał, że mianowanie biskupa to trochę jak przygotowanie figurki świętego do umieszczenia w kościelnej niszy. Kościoły, zwłaszcza barokowe, są ozdobione bardzo wieloma statuami świętych, umieszczonymi w bardziej czy mniej ozdobnych niszach.

Zanim artysta wyrzeźbi statuetkę, musi najpierw dokładnie zmierzyć niszę, musi ją obejrzeć, sprawdzić, z czego jest zrobiona, czy jest prosta, czy bogato zdobiona, czy jest położona wysoko, czy nisko na ścianie. Tylko w ten sposób będzie wiedział, jakiej wielkości, z jakiego materiału i w jakim kolorze przygotować posąg świętego.

Jeśli chodzi o obsadzanie diecezji, niszą jest diecezja, a posągiem kandydat na jej pasterza. Konsultacja miejscowej wspólnoty kościelnej to sposób na „oględziny” niszy. Osoby konsultowane są proszone także o wskazywanie nazwisk ewentualnych kandydatów na biskupa; na wskazywanie takich „posagów”, które będą dobrze pasowały do tej właśnie niszy, którą wcześniej opisywali.

Pewną dodatkową formą uczestniczenia miejscowej wspólnoty kościelnej w wypracowywaniu nominacji papieskiej, niewzmiankowaną w cytowanych dokumentach, która jest jednak praktykowana, jest konsultacja sua sponte, z własnej inicjatywy. Dziś, gdy poczucie demokracji jest powszechne, gdy czuje się wolność w wypowiadaniu własnych sądów i chęć uczestniczenia w tym, co się wokół nas dzieje, wielu ludzi, katolików i nie-katolików, a nawet czasem niewierzących, którzy z zainteresowaniem patrzą na sprawy Kościoła i jego obecność w życiu, z własnej inicjatywy piszą do nuncjusza i wyrażają swoje opinie w tych sprawach. Także takie głosy często okazują się przydatne i skuteczne. 


\section{The Role of the Particular Church in the Procedure of Nominating Bishops by the Pope}

Summary

The nominations for bishops are very important for the Church. They are considered as very ticklish and requiring delicacy. The article aims to show the role of the particular Church in the procedure. The past and today practices are presented, as well as legal foundation of the process.

Keywords: bishop, the particular Church, pope, nomination, canon law 
